Zoologica Poloniae (2013) 58/1-2: 29-36

DOI: $10.2478 /$ zoop-2013-0003

\title{
DO FISH HAVE RIGHTS IN ARTISANAL FISHERIES?
}

\author{
Moshood K. Mustapha
}

Dept. of Zoology, University of Ilorin, Ilorin, Nigeria

E-mail:moonstapha@yahoo.com

\begin{abstract}
Artisanal fishers in the developing world are unaware that fish are capable of suffering or experience discomfort, though researches have shown that fish do feel pain. Five fish welfare domains have been identified which constitute their rights in their environment. The needs of wild fish are usually provided in their natural, undisturbed and unperturbed aquatic environment, of which the fish will prefer. However, various anthropogenic activities by humans (including artisanal fisheries themselves) and some natural perturbations in the watershed, riparian zone, water body of the fish habitat and on the fish tend to take away these needs thereby compromising the fish welfare. These activities include environmental degradation, boat/canoe building, use of motorized boats/canoes, use of active and passive fishing gear, obnoxious cultural, religious and social fishing practices, fish harvesting, handling and processing among others. One way to understand the welfare needs of an individual fish is to understand its biology. Poor welfare conditions can then be assessed by how far the individual fish has deviated from the normal conditions. Non-intrusive signs based on the health, behaviour, morphological anomalies, swimming, reduction in population and growth, outbreak of parasitic infections, injuries and loss of condition can be used to assess fish whose welfare has been compromised. Artisanal fishers should not only be concerned with catch, but, also the welfare of the fish being caught. This is because if the welfare of the fish is compromised, it is going to definitely affect the catch. As indispensable as fish are to humans, humans should not derive their pleasure at the expense of fish suffering. Human activities that impinge on the welfare of wild fish may not necessarily be stopped, but should at least minimized in order to have continued sustainable artisanal exploitation of the fisheries.
\end{abstract}

Key words: welfare, artisanal fisheries, developing world, stress, behaviour, feel, habitat 


\section{INTRODUCTION}

The welfare rights of fish in artisanal fisheries, especially in developing countries of the world, are usually not thought of by the fishermen and other stakeholders in the industry as opposed to the industrialized world which nowadays considers that fish are entitled to good welfare. The United Kingdom's Farm Animal Council (FAWC 1979) identified five rights known as five freedoms for farm animals (Cattles, Pigs, Sheep and Chicken) with the exclusion of fish initially, but fish were later considered and included (FAWC 1996).

Many workers such as Dawkins (2006), Duncan (2006), Huntingford et al. (2006) agreed that animals are capable of suffering or feeling discomfort, but fish welfare is often neglected especially in artisanal fisheries of underdeveloped and developing countries of Asia and Africa. The reasons for this may stem from assumptions that fish do not experience any form of suffering or discomfort in their natural habitat, but scientists have shown that fish are capable of suffering (Dawkins 2006, 2008, Huntingford et al. 2006, Volpato et al. 2007, 2009). According to Volpato et al. (2006), fish deserve welfare attention because of their strategic phylogenetic position among the vertebrate. Thus, studies relating to fish welfare are just beginning to emerge.

The OIE (World Organization for Animal Health) (2001) defines animal welfare as animals being healthy, comfortable, well nourished, safe, able to express innate behaviour and not suffering from unpleasant states such as pain, fear or distress. It therefore means that good animal welfare including wild and captive fish requires disease prevention and treatment, good shelter management, nutrition and humane handling during capture and killing. HunTINGFORD et al. (2006) defined the welfare of fish according to the feeling of the fish where the fish should feel well, be free from pain, fear or aversive conditions, while Volpato et al. (2007) defined fish welfare as the internal state of the fish when it remains under conditions that were freely chosen. Other workers' definition of fish welfare relates to function, where the fish should be in good health, should be able to lead a natural life and express its natural behaviour.

This review is about the neglect of fish rights by people involved in artisanal fisheries especially in developing countries of Africa and Asia. It is also aimed at highlighting those human activities related to artisanal fisheries in the developing world that compromise fish welfare in the natural habitats, as well as bring out the importance of maintaining good fish welfare for continued sustainable artisanal exploitation of the resources in developing countries of the world.

\section{The issues of fish welfare in artisanal fisheries of the developing world}

Artisanal fisheries involve the capture of fish from the wild (natural aquatic ecosystem) using traditional or small scale fishing gear (nets, traps etc) and motorized or non-motorized vessels (dugout boats and canoes) (MUSTAPHA 2013). Artisanal fishermen use a relatively small amount of capital, energy and equipment for fishing activities, and the fishing trips are often short or none at all 
close to the shore, while the fish caught are sold locally or consumed by the household.

Artisanal Fisheries account for about $30 \%$ of GDP of developing countries, while $5 \%$ of the population, about 35 million people, depends wholly or partly on artisanal fisheries for their livelihood (FAO 2004). Artisanal fisheries dominate fish production in many of the developing countries of Africa and Asia contributing about $80 \%$ of fish production, since aquaculture that could compliment the fisheries is not well developed especially in the continent of Africa.

Fish welfare could be compromised by anthropogenic or sometimes autogenic (natural) perturbations in the aquatic ecosystem and its processes, and if the fish welfare is thus compromised by these activities, the fish health, sustainable livelihood and socio-economic characteristics of the fishermen could become seriously undermined.

A good fish population is one in which the welfare needs of all individuals in the population are met in their natural environment. Morphological, physiological, behavioural and environmental states of individual fish constitute their welfare. Duncan (1981) noted that welfare is a characteristic of an individual animal and is concerned with the effects of all aspects of its genotype and environment on the individual. The welfare of a fish in artisanal fisheries will largely depend on its habitat and the ability to cope with ever changing habitat caused by several human activities, autogenic bottom-up and top-down processes in the aquatic ecosystem and the new challenge of climate change. A way of understanding the welfare needs of a fish species is to know the biology of the species. The biology of many aquacultural species are known due to their importance, but that of a large number of wild species, many of them captured in artisanal fisheries, remains unknown. The welfare needs of such unknown species could only be viewed in relation to the known biology of related species which could only be useful as index but might not give a satisfactory assessment of the welfare. Morton and Griffiths (1985) observed that poor welfare conditions can be assessed by how far an individual animal has deviated from what is normal for animals in that environment and comparing it with other kinds of animals found in the same or similar environment. The welfare of fish in artisanal fisheries in developing world is critical and not usually considered to be of any importance once the fish are captured. It is of concern only if the species being captured are caught dead, inedible, unmarketable or are of lower market value.

Fish needs are usually provided in their natural, undisturbed and unperturbed aquatic environment, of which the fish will prefer. However, various human activities (including artisanal fisheries themselves) in the fish aquatic habitat such as the watershed, riparian zone, water body and on the fish tend to take away these needs and put the welfare of the fish in serious jeopardy. Many times, the response of fish to a lack or denial of these needs is slow, unseen and unnoticed. Also, different fish species show different behavioural responses to nociceptive events (Reilly et al. 2008). It is, however, clear that wild fish could become stressed, feel pain and discomfort, fear stricken, display 
abnormal behaviour, injured, vulnerable to or even diseased if the threshold of their environment is below the optimum for the fish. These signs of 'bad' welfare become more manifest if the coping mechanisms in the fish can no longer cope with the magnitude of the stressors. Fish that lack welfare needs could easily be noticed through deviations from their normal biological state, while the fish that has 'all' the welfare needs could be seen through its pleasurable manner in terms of swimming, behaviour, emotion, etc.

\section{Activities compromising fish welfare in artisanal fisheries of developing countries}

A comprehensive review of human activities that could potentially compromise wild fish welfare has been provided by FSBI (2002) and Huntingfold et al. (2006). Artisanal fisheries take place in and around water bodies with the fish being the sole target of the trade. Various watershed activities related to artisanal fisheries which might compromise fish welfare in their natural habitat has been discussed by Mustapha (2009). Many other artisanal fisheries activities such as boat and canoe building, fish descaling, processing, etc. wash the by-products of these activities into the water body thereby affecting the aquatic ecology, water quality, primary and secondary production, etc, all of which produce a synergistic impact on fish welfare. The use of motorized dug out boats/canoes with outboard engines in artisanal fisheries could compromise the welfare of fish through the pollution of the water body with oil and other lubricants used in the engine. Also, emissions and effluents from the engine will impair fish welfare, while noise generated from the engine could cause fear in the fish and the outboard engine propeller may cause physical injury to the fish. As stressed by Montgomery \& Needleman (1997), environmental degradation is clearly a cause of poor welfare in very large numbers of fish.

The capture of fish in itself causes harm to fish. For instance cortisol levels increase during capture (СноріN \& АRाмото 1995), this impairs disease resistance and results in poor growth (FSBI, 2002). Slaughter methods are also highly stressful (PoLI et al. 2002), especially the ones used in artisanal fisheries of the developing world which involve asphyxiation. The use of different types of active and passive gear such as spears, harpoons, gaffs, clubs, arrows, traps, pots, dredges, hook and lines, cast nets, gill nets, long lines, seines and other traditional fishing gear used in artisanal fisheries in Africa and Asia and their methods of use cause serious injury and mortality to the fish to the extent that some of the fish caught by these methods become 'useless'. In order to maximize catch, artisanal fishers use different obnoxious fishing practices to catch fish, all of which impair the welfare of the fish. Some of these practices include the use of chemicals, explosives, poisonous baits and attracting lights.

Many artisanal captures of fish are used for religious, cultural and social practices in developing countries. The capture of fish for these practices is usually detrimental to the welfare of individual fish species targeted and the general population of the fish in the habitat. Conte (2004) suggested that fish harvesting should be done in a sustainable way that will not impose an excessive cost to nature and also maximize fish welfare. 


\section{How do artisanal fishers know when fish welfare is compromised?}

Artisanal fishers could assess the welfare of the fish to be captured through the use of non-intrusive signs or danger signals that can be used easily, without the involvement of complicated laboratory analysis. Most assessments could be based on the health, behaviour, morphological anomalies, swimming, reduction in population and growth, outbreak of parasitic infections, injuries and loss of condition which are seen in the individual fish and the population and which appear to deviate from the other fish in the same or similar environments.

Fish are very sensitive to a wide range of stimuli which could inflict pain, suffering and injury. Many signs and symptoms of fish to adverse conditions are seen in their behavioural, morphological and physiological states. A deviation from the normal behavioural, morphological and physiological states is an indication of stress response in the fish. Though fish posses a suite of adaptive behavioural and physiological strategies that have evolved to cope with destabilizing challenges and stressors (HungtingFord et al. 2006), it is when the "coping strategies" are stretched above the limit that the stressors take over and manifest in the abnormal behaviour, physiology or morphology seen in the fish. The „coping strategies” in fish should therefore not be seen as endurance to pain or that fish do not suffer from welfare impairment. Artisanal fishers should use a range of measures in the fish which will provide a more accurate assessment of welfare rather than a single measure such as body colour or swimming behaviour. This is because of the variety of coping mechanisms used by the fish (Koolhans et al. 1999, Huntingford and Adams 2005) and the various effects of the environment on individual species of fish.

\section{The rights of fish in their natural habitats which constitutes their welfare}

From moral, cultural, ethical and practical perspectives, it could be seen that fish have rights in their own world. These rights which are linked to their welfare are often ignored in artisanal fisheries, but are usually taken into consideration in culture fisheries for successful production. The rights of fish in their natural habitats are simply described as their five welfare domains specified by Mellor \& StafFord (2001) and which have been highlighted by FSBI (2002). They are:

1. Water and food deprivation, malnutrition: Fish should have access to an adequate, nutritionally complete diet, taking into account the fact that fish vary greatly in their natural diet, that they do not need to maintain a constant body temperature and that in many cases they show marked differences in requirements with season and life history stage.

2. Environmental challenge: Water quality, flow rates and temperature and other physico-chemical and biotic components of the habitats appropriate for the species should be maintained. Seasonal and daily patterns of light intensity are also appropriate.

3. Disease, injury and functional impairment: Diseases, parasitic infections and injury should be prevented or rapidly diagnosed and treated where possible. 
4. Behavioural/interactive restriction: Fish should have sufficient space to allow a degree of freedom of movement, but the definition of 'sufficient' will be species-specific. For shoaling species, the company of their own kind is important for welfare, but for territorial species, this may not be the case. A degree of environmental complexity may be important, depending on the species concerned.

5. Mental and physical suffering: Conditions that produce unacceptable levels of anxiety, fear, distress, boredom, sickness, pain, hunger and so on should be minimized.

In the case of artificial environments, the five welfare domains are often given utmost attention for the successful production of fish. Compromising any of the five welfare domains in aquacultural production in an artificial environment will lead to loss of investments. Thus, aquaculturists make fish welfare an important consideration for fish production in artificial environments.

\section{CONCLUSION}

Artisanal fishers should not only be concerned with catch, but also the welfare of the fish being caught. This is because if the welfare of the fish is compromised, it is going to definitely affect the catch. When the fish are stressed or their welfare impaired, mortality, migration and loss of recruitment could occur thereby affecting catches. Fish are not regarded as having feelings by fishermen and are thus less protected and not given adequate rights they deserve in artisanal fisheries of the developing world. This is in spite of the fact that the concept of welfare is the same for all the animals, i.e. mammals, birds and fish, used for human food and given protection under the Treaty of Amsterdam.

As indispensable as fish are to humans, humans should not derive their pleasure at the expense of fish suffering. Many more pressing motives for minimizing human impact on the environment are seen than concern for fish welfare in the same environment. Artisanal fisheries should always consider fish requirements and welfare and should impose the least discomfort possible throughout the fisheries process. Also, if fish discomfort or any other sign of fish suffering is noticed, remedies should quickly be put in place to lessen the pain. Human activities that impinge on the welfare of wild fish may not necessarily be stopped, but at least minimized. Fish handling, transportation, slaughter and exposure to air after catch should be minimized, while fishing in extreme water temperatures and the use of certain types of traditional fishing gear should be eliminated to reduce injury, stress and mortality.

Developing countries need to adopt fish welfare protocols and legislation should back it up. Ignorance of fish rights should not be an excuse to infringe on these rights. In this manner, fish advocacy and conservation groups could help through education, enlightenment and awareness campaigns to promote welfare issues of fish to artisanal fishermen. 
Since the science of fish welfare is just beginning to emerge, research on behavioural responses of different species of fish to different artisanal fisheries activities in the watershed, riparian zone and water body need to be conducted to evaluate how these activities compromise fish welfare and infringe on their rights.

\section{CZY POŁAWIANE RYBY MAJA PRAWA W RYBACTWIE TRADYCYJNYM (NIE-PRZEMYSŁOWYM)?}

\section{STRESZCZENIE}

W rybactwie tradycyjnym - uprawianym na skalę mniejszą niż przemysłowa (artisanal fisheries) zwykle nie bierze się pod uwagę zdolności ryb do odczuwania bólu i cierpienia. Określono pięć parametrów ich dobrostanu, które formują ich prawa $\mathrm{w}$ środowisku naturalnym. Potrzeby dzikich ryb są zaspokajane przez ich naturalne, niezaburzone antropogenicznie siedliska, podczas gdy wielostronne ludzkie oddziaływania wpływają na nie jednoznacznie negatywnie.

Podstawą do zrozumienia potrzeb tych zwierząt jest gruntowne poznanie ich biologii. Jako wskaźniki pozwalające na ewaluację kondycji dobrostau ryb mogą być stosowane zarówno cechy biologiczne (osobnicze) jak: behawior, anomalie morfologiczne, charakterystyka pływania, jak i populacyjne: redukcja liczebności, inwazja parazytologiczna, poranienia ciała czy utrata biomasy. Rybactwo nie-przemysłowe powinno koncentrować się nie tylko na zysku z połowu, ale i na dobrostanie poławianych ryb. Nie oznacza to że ten typ rybactwa powinien zostać wyeliminowany, ale że należy dbać o minimalizacje cierpienia ryb przy zrównoważonym jego rozwoju.

\section{REFERENCES}

Chopin F.S. and Arimoto T. 1995: The condition of fish escaping from fishing gears a review. Fisheries Research 21: 315-327.

Conte F.S. 2004: Stress and the welfare of cultured fish. Applied Animal Behavioural Science 86: 205-223.

Dawkins M.S. 2006: Through animal eyes: What behaviour tells us. Applied Animal Behavavioural Science 100: 4-10.

Dawkins M.S. 2008: The science of animal suffering. Ethology 114: 937-945.

Duncan I.J.H. 1981: Animal behaviour and welfare. In: Environmental aspects of housing for animal production. Butterworths, London UK,

Duncan I.J.H. 2006: The changing concept of animal sentience. Applied Animal Behavavioural Science 100: 11-19.

FAO (Food and Agriculture Organization), 2004: The State of World Fisheries and Aquaculture 2004. FAO, Rome.

FAWC (Farmed Animal Welfare Council) 1996: Report on the Welfare of Farmed Fish. Surbiton, Surrey.

FSBI 2002. Fish Welfare. Briefing Paper 2, Fisheries Society of the British Isles, Granta Information Centre, Cambridge, UK. 
Huntingford F., Adams C. 2005: Behavioural syndromes in farmed fish: implications for production and welfare. Behaviour 142: 1207-1221.

Huntingford F., Adams C., Braithwaite V., Kadri S., Pottinger T., Sandoe P., Turnbull J. 2006: Current issues in fish welfare. Journal of Fish Biology 68 (2): 332372.

Koolhaas J.M., Korte S.M., De Boer S.F., van der Vegt B.J., van Reenen C.G., Hopster J., De Johng I.C., Ruis M.A.W., Blokhuis, H.J. 1999: Coping styles in animals: current status in behaviour and stress-physiology. Neuroscience and Behaviour Reviews 23: 925-935.

Mellor D.J., Stafford K.J. 2001: Integrating practical, regulatory and ethical strategies for enhancing farm animal welfare. Australian Veterinary Journal 79: 762768.

Montgomery M., Needleman M. 1997: Welfare effects of toxic contamination in freshwater fish. Land Economics 77: 211-223.

Morton D. B., Griffiths P.H.M. 1985: Guidelines on the recognition of pain, distress and discomfort in experimental animals and an hypothesis for assessment. Veterinary Record 116 (16): 431-436.

Mustapha M.K. 2009: Influence of watershed activities on the water quality and fish assemblages of a tropical African reservoir. Turkish Journal of Fisheries and Aquatic Sciences, 9: 01-08.

Mustapha M.K. 2013: Potential Impacts of Climate Change on Artisanal Fisheries of Nigeria. Journal of Earth Science and Climate Change 4: 130. doi: 10.4172/ 2157-7617.10001.30

Poli B. M., Zampacavello G., Iurzan F., de Francesco M., Mosconi G., Parisi G. 2002:

Biochemical stress indicators changes if sea bass as influenced by slaughter method. In Sea farming Today and Tomorrow. (Basurco, B. \& Sargolia, M. eds), pp. 429-430. European Aquaculture Society Special Publication 32.

Reilly S.C., Quinn J. P., Cossins A.R., Sneddon L.U. 2008: Behavioural analysis of a nociceptive event in fish: Comparisons between three species demonstrate specific responses. Applied Animal Behaviour Science 114 (1-2): 248-259.

Volpato G.L, Trajano E. 2006: Biological rhythms. In: Val L.A, Val V.M.F.A., Randal D.J (Org). Fish Physiology. San Diego: Elsevier. p 101-153.

Volpato G.L., Gonçalves-de-Freitas E, Fernandes-de-Castilho M. 2007: Insight into the concept of fish welfare. Diseases of Aquatic Organisms 75:165-171.

Volpato G.L., Giaquinto P.C, Fernandes-de-Castilho M., Barreto R.E, GonçalvesdeFreitas E. 2009: Animal welfare: From concepts to reality. Oecologia Brasiliensis 13: $5-15$.

World Organisation for Animal Health (OIE) (2001). - OIE Third Strategic Plan, 20012005.

\section{Electronic publications:}

FAWC (Farm Animal Welfare Council) 1979. Press statement

http://www.fawc.org.uk/pdf/fivefreedoms 1979.pdf 